\title{
IDEOLOGY AND FACTS ON AFRICAN AMERICAN ENGLISH ${ }^{1}$
}

\author{
Salikoko S. Mufwene
}

\section{Introduction}

The term "African American English" (AAE) is used in this essay to refer to the vernacular spoken by African Americans particularly in urban ghettoes and rural areas of the USA, with of course the exception of some coastal isolates of South Carolina and Georgia, where Gullah is spoken (see also Labov 1972a). The features discussed below apply especially to its basilect, that variety that is the most different from middle-class varieties of American English.

The term "ideology," suggested by Spears (in press), is used here in a slightly different way related to the Kuhnian sense of "paradigm," i.e., a particular body of working assumptions adopted by a school of researchers. These assumptions "color" their analyses of data to some extent, determine some of their justifications for rejecting alternative views, and account for the orientation of their subsequent research on the subject matter.

In the case of AAE, one of the factors most relevant to this paper is the positions of various linguists on its genetic status. The question is three-fold: 1) Has AAE always been different from Gullah and its Caribbean kin but closer to white American nonstandard English (WANSE) varieties with a grammar that can be traced back mostly to nonstandard varieties of British English and/or to sixteenth-toeighteenth-century maritime English? 2) Did AAE start as a Gullah-like creole and subsequently lose some, or several, of the latter's features through a putative process

1 This paper was originially written for an anthology on language, symbolism, and ideology, edited by Arthur Spears. Per the advice of referees who thought it was too technical for a volume intended for non-linguists and in which there are hardly any other linguistic papers, it had to be withdrawn. I am still grateful to Art for commenting candidly on its first, more technical and longer version, written in 1987, and for encouraging me to submit this revised, still "watered-down" version elsewhere. I regret not following all his suggestions literally. I also thank Joey Dillard and Jessica Cooper for feedback on one of the ancestors of this essay, as well as Marcy Morgan for convincing me to submit the latest version to Pragmatics, when I thought that it might be easier to table it and stay out of yet another disagreement with the establishment on African American English. The final comments from my anonymous reviewers were well appreciated. I assume alone full responsibility for all the remaining shortcomings. 
of decreolization ${ }^{2}$ in such a way that it now has basically the same grammar as some WANSE varieties? 3) Did AAE start as a Gullah-like creole but continue to use a creole-like grammar despite its putative decreolization?

I wish to show that many of the partial explanations of AAE grammar proposed in the literature can be correlated with the ideology factor. It accounts for why the proponents of the different positions presented below have held somewhat too rigidly to their views in spite of their partial shortcomings, have downplayed facts that they cannot account for, and have not looked for alternatives beyond their own and those of their opponents.

Since the factor invoked above is central to this essay, I wish to elaborate a little bit on it here, before discussing data that bear on my thesis. From the point of view of AAE's grammar today, it is plausible to reduce the three positions on its genetic status to only two. The first lumps together alternatives 1 and 2 above, which have been adopted respectively by linguistic geographers such as George Krapp, Hans Kurath, Raven McDavid, Jr., Juanita Williamson, and more recently Edgar Schneider and by sociolinguists such as William Labov, Ralph Fasold and Walter Wolfram. It may be called the dialectologist or English-dialect position. According to this, AAE is but an English dialect of basically the same kind as WANSE varieties. It differs from them essentially either in having preserved features which are no longer used by Whites (Krapp 1924; McDavid 1950; McDavid \& McDavid 1951) or in applying more generally rules which are rather more restricted in WANSE (Labov 1972b; Burling 1973). For instance, regarding the "absence of the copula" (i.e., the linking verb be) in John sick 'John is sick,' the difference between AAE and WANSE lies allegedly not so much in whether or not WANSE applies what sociolinguists call "copula deletion rule" but rather in the fact that the putative rule applies more frequently and is less restricted in $\mathrm{AAE}^{3}$

2 The term "decreolization" has been used for the process by which a creole putatively departs further and further away from its basilect and presumably closer and closer either to its lexifier (the language that gave it the greater proportion of its vocabulary) or to its acrolect (the local prestige variety). The term has been used even when the change is suggested only by the smaller proportion of speakers of the basilect. Unfortunately, the evidence for the process has generally been adduced from the variable features of today's speech varieties, not from historical documentation. For dissentient discussions of this process see Mufwene (1987, 1988, 1991a, 1991b).

3 The label "dialectologist position" does not entail complete denial of creole or African influence in the structure of AAE. In fact Raven McDavid was one of the earliest supporters of Lorenzo Turner's (1949) Africanisms in the Gullah dialect, although he advised caution against extrapolations and rightly reminded fanatic substratists of the relevance of British dialectal features in the study of both black and white southern speech varieties (McDavid 1950; McDavid \& McDavid 1951). Most "dialectologists" also admit that AAE does have some grammatical peculiarities which are not attested in "other dialects of English" and may be related to pidgin/creole or some African linguistic structures (see the examples in the main text). Schneider (1992) is a case in point, elaborating on aspects of AAE structure that the English-dialect hypothesis does not account for. Likewise, the assumption of the other positions discussed below does not entail the rejection of British dialectal influence on AAE either; the issue really is whether assuming the English or creole grammatical system 
The second position, corresponding to the third alternative above, is known as the creolist position, adopted originally by Beryl Bailey, William Stewart, and Joey Dillard. According to this, the similarities between AAE and WANSE are only superficial; the grammar of AAE is fundamentally related to that of Atlantic pidgins and creoles (henceforth PC, e.g., Gullah, Jamaican creole, or Cameroon Pidgin) and ultimately to the sixteenth-century West African Pidgin English from which it is putatively derived (Stewart 1967/1975: 229, 1968/75: 235, 1974: 14; Dillard 1972, 1985). Thus, for instance, it is claimed that no copula is missing in the sentence John sick; instead, sick functions as an adjectival predicate (more or less like a verb). The contracted copula which appears in constructions such as John's sick is allegedly the result of decreolization (Stewart 1968/1975: 234, 1974: 15) ${ }^{4}$. On the other hand, the presence in WANSE of some non-standard phenomena which are more frequent in AAE (e.g., he be drunk 'n singin' every night) is attributed in some cases to the latter's influence on the former (Stewart 1967, 1974; Dillard 1972). This is evidently a rejection of the old dialectologist position since Krapp (1924) that AAE might be a more conservative variety which was once used alike by European and African Americans of the same socio-economic class.

A third position, adopted particularly by David Dalby (1971), Ernest Dunn (1976), and Ivan Van Sertima (1976), is an extrapolation of the creolist view and claims that the grammar of AAE is ultimately related to common features of (West) African languages, on which Atlantic PCs themselves are grammatically based. This is the strong substratist position, built on Sylvain's (1936) and Turner's (1949) claims that

as underlying AAE provides a more adequate analysis of the grammatical facts of this language variety. In a different vein, the traditional term "dialectologist position" used here to lump both traditional dialectologists and sociolinguists (in spite of differences in their methodologies and interests) is likely to displease some linguists. (Bailey and Maynor's 1987 term "anglicist" could do as well.) What justifies lumping them together here (unlike in, e.g., Montgomery 1983, or Montgomery and Bailey 1986) is essentially their common assumption that underlyingly the grammatical system of AAE is largely the same as that of WANSE. It will also help to note that even in alternative classifications (just as here) some (relatively secondary) differences among the sociolinguists themselves must be overlooked too. For instance, although Wolfram believes that the differences between AAE and WANSE are rather superficial, he indeed questions the Labovian deletion rules to account for the zero copula, and for the absence of markers of tense, nominal number and possessive delimitations, etc. (1971). On the other hand, Labov $(1972 b, 1982)$ and Fasold $(1976,1981)$ believe in the creole ancestry of AAE; however, they see its decreolization (qua assimilation to English) as so far advanced as to have rendered the differences between it and WANSE only superficial and regarding statistics.

4 There is an alternative creolist interpretation of the presence of the copula in such constructions, viz., given the continuum which characterizes creole speech communities, more than one particular construction or grammar have been used by AAE speakers. These constructions have always varied from creole-like to WANSE- or standard English-like, and the greater frequency of one or the other type need not correspond to decreolization (see Schneider 1982, 1990 and Mufwene 1984b, 1991c). In fact, according to G. Bailey (1987), Bailey and Maynor (1987), and Labov (1987), AAE has been diverging from, rather than converging with, English grammar. See particularly Spears (1987) and Butters (1989) for a word of caution on this divergence hypothesis. 
Haitian creole and Gullah are European-related only on the surface, their grammars are otherwise (West) African-based.

The strongest arguments for the above substratist position have been based on some phonological, lexicosemantic and cultural "continuities" ${ }^{\text {"5 }}$ from Africa (the latter two particularly stimulated by the work of Herskovits, e.g., 1941). Grammatical evidence has been rather sketchy. The most compelling of this appears to lie in Gullah's archaic comparative and superlative constructions with a verb meaning 'pass' (as in $A l$ tall pass Teddy ' $\mathrm{Al}$ is taller than Teddy'), in the verbal characteristics of predicative adjectives (e.g., in doing without the copula as in John sick), and in the use of a special marker for the habituative aspect (e.g., John be talkin' every time I see him; Turner 1949; Van Sertima 1976). It is the dialectologist and creolist positions (the latter of which has often been confused with the substratist position, even in Mufwene 1983a) which are based mostly on grammatical considerations. Fairly extensive analyses advocating these positions have been primarily on time reference, negation, the copula (see Part 2 below), number and the possessive delimitations, and a few others.

On the other hand, an alternative to all the above positions, according to which AAE may have always been a separate language variety of its own, derived from neither a creole nor any WANSE variety though it is structurally related to both (Mufwene 1987; Holm 1988; Schneider 1990) is quite conceivable. Although this other alternative is not explicitly proposed here, it underlies much of the discussion in this essay.

The rest of this paper is divided into small parts corresponding to two of the aspects of AAE grammar enumerated above, viz., the copula and time reference, which have been the most thoroughly discussed in the literature. Veterans in the field will notice that what is presented is still sketchy; but my purpose is primarily to demonstrate that neither the creolist nor the dialectologist position accounts satisfactorily for the facts of AAE grammar. Whichever position is taken, there are still aspects of AAE which beg the question and call for a fresh approach to the subject-matter. In each case the essences of the main positions are summarized and evaluated, showing how partial they remain and highlighting their respective strengths and shortcomings. Since, as indicated above, the substratist position is essentially an extrapolation of the creolist position, it is largely overlooked until Part 4 , where it is discussed very briefly and globally, just before the general conclusions of the paper are drawn in Part 5.

\footnotetext{
${ }^{5}$ It is with reluctance that the term "continuity," which has alternated in the literature with the terms "survival" and "retention," is used here in relation to the lexicon and semantics (see Mufwene 1985a). With regard to language, the term "selection" (borrowed in my other writings from Gilman 1981 ) is preferable, particularly because it is rather neutral, giving primacy to neither European nor African languages regarding the structure of PCs and AAE. It admits the fact that, aside from possible innovations, both African and European languages have contributed something to the grammars of these new languages.
} 


\section{The copula ${ }^{6}$}

With the exception of Wolfram, sociolinguists assume that beyond their prima facie differences AAE and WANSE are similar regarding their usage of the copula to link to the subject of a sentence either a predicative noun or adjectival phrase, a locative adverbial or a prepositional phrase, or a verb in the present or past participle, as in the following sentences. (The parts of the sentence identified between parentheses are emphasized.)

(1) a. John is the leader. (predicative noun phrase)

b. John is tired. (predicative adjective)

c. John is out there. (locative adverbial)

d. John is with Mary. (prepositional phrase)

e. John is working. (present participle)

f. John is scared. (past participle)

In both language varieties the copula can be contracted to a shorter ' $m$ (as in I'm fine), 's (as in she's fine), or 're (as in we're fine), and sometimes it can be omitted. When it is omitted, as in the following sentences (adapted from Labov 1972b and DeBose 1984b), it is putatively deleted by a phonological rule after the contraction rule has applied:

a. John the leader. <--- John's the leader. <--- John is the leader.

b. John tired. <--- John's tired. <-- John is tired.

c. John over there. <--- John's over there. <--- John is over there.

d. John workin'. <--- John's working. <--- John is working.

e. John gon(na) come. <-- John's gon(na) come. <--- John is going to come.

The following facts, ordered $A$ to $D$, have been adduced as evidence for the Labovian deletion rule:

A) The copula is always present in what Labov (1982) calls "exposed position," particularly in sentence-final position, in imperative and infinitival clauses and after modal verbs (e.g., may, can, and must), in emphatic and elliptical clauses (e.g., short answers to yes/no questions), and in tag questions, as in the examples below. (The asterisk in

${ }^{6}$ Traditionally, the term "copula" has been used for the verb "be' as a connector of the subject and adjectival, prepositional, or some adverbial predicate phrases, as in John is at home. However, in studies of AAE (particularly since Labov 1969), it has also been used for the auxiliary-verb be in the progressive (as in John is singing), in future constructions with going (to)-typically reduced to gon(na) in AAE), and in passive constructions. Analyses of English that treat the copula itself as an semantically empty verb that is used only for syntactic purposes, just like the verb do in negative and interrogative sentences (see Rosenbaum 1968, generative semantics; Mufwene 1983a; Dik 1983), should find no problem in this extension. After Dik (1983), Mufwene $(1989,1991 \mathrm{c})$ argues that the traditional copula itself is a syntactically-motivated auxiliary verb used to create a verb phrase where the head of the predicate phrase (semantically speaking) is not a verb. 
front of the parentheses indicates that the sentence is ill-formed if the parenthesized forms - here, the copula - is omitted; the slash separates alternative forms in the particular position where they are shown. Most of the examples are from Labov 1969/1972a.)
a. He might * (be) over there. (after a modal verb)
b. I Ion't care what you *(are/is). (sentence-final position)
c. $\quad$ Don't *(be) messin' with my old lady. (negative imperative) $)^{7}$
d. $\quad$ *(Be) nice to your brother. (imperative)
e. We gon *(be) eatin breakfast. (infinitive)
f. $\quad$ Larry home? -- Yes, he is ${ }^{*}$ o. (elliptical/sentence-final) ${ }^{8}$

B) The form was which occurs in some past constructions, as below, is nothing but the past tense of the copula (Labov 1969).
a. He was the leader.
b. We was tired.
c. They was over there.
d. He was workin'.
e. John was gon come.

C) The been which occurs in constructions such as I been sick or We been over there is derived from the have been (perfective) construction of other dialects of English, from which the auxiliary verb have has been deleted (D'Eloia 1973; Fasold and Wolfram 1975).

D) Constructions such as below are often attested in AAE, which prove that its grammar does have a copula and this is deleted only optionally in some contexts (Labov 1969):

(5) a. I'm sick.

b. Tha's my sister.

c. Wha's happenin'?

d. Are you done?

However, creolists have claimed, that in most of the above constructions the copula is inserted, particularly before adjectives and prepositions (which behave like verbs in creole grammar - see Mufwene 1983b), and in the progressive and future constructions. It is precisely in these contexts, based on the following statistics rounded

7 This negative imperative environment does not count if be is interpreted as the habitual marker, because it is not a copula.

${ }^{8}$ Worth noting in connection with this is also the use of the auxiliary verb do in similar elliptical sentences involving verbal predicates which are not in the progressive and involve no other auxiliary verb (the case of distributive be discussed by Fasold 1969 excluded), as below:

(i) I know Ron work here. . yes he do.

Space limitation will, however, not allow us to discuss this aspect of BE grammar, which also supports the dialectologist position. 
from Labov (1969), that the incidences of zero copula exceed those of the contracted or full copula. The higher frequency of full and contracted copulas before a N(oun) $\mathrm{P}$ (hrase) corresponds to a relexification of the PC equative verb da/duh [dz] in Gullah, or $d e[\mathrm{~d} \epsilon]$ in Jamaican and Guyanese creoles through the process of decreolization (Stewart 1970: 244). More discussion below. ${ }^{9}$

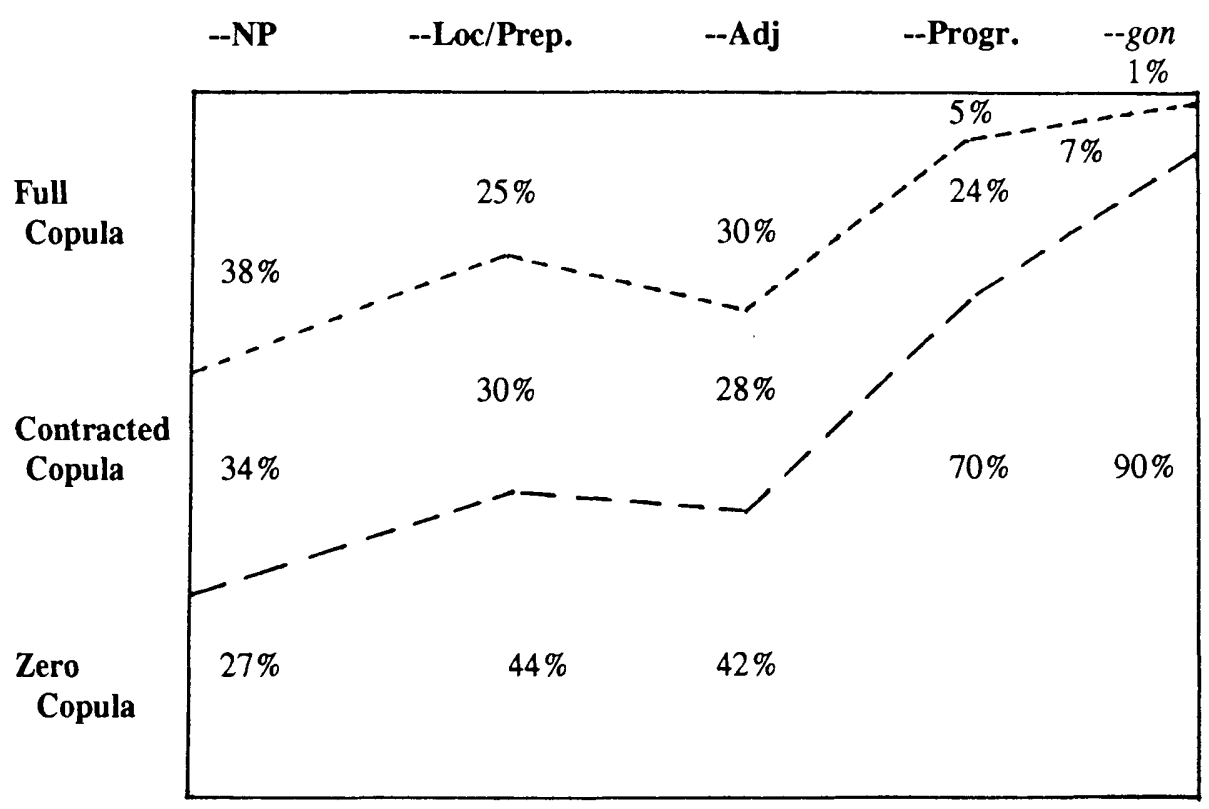

\section{Diagram A}

It has been argued contra dialectologists' evidence $\mathrm{D}$ that the use of the copula in these constructions does not conform with English grammar, since constructions such as He am sleepin, I'm am sick, and I'm is sick have been heard (Stewart 1966; Dillard

${ }^{9}$ The figures in both Diagram A and B have been averaged from Labov's (1972: 86) Table 3.2, combining the percentiles for the Thunderbirds and the Jets and dividing them by two. The order of adjectives and locative/prepositional phrases has been adjusted to conform with his diagrams in Figure 3.5 (p.87). 
1972; Alleyne 1980; DeBose 1984a; statistical distribution not provided). ${ }^{10}$ This suggests that, at least for some speakers, I' $m$ is not analyzed as the contraction of $I$ and am but as an alternative first person pronoun of the singular. ${ }^{11}$ To continue the creolist argument, constructions such as I'm tired and I'm sick for such speakers consist of a personal pronoun plus an adjectival predicate with a zero copula (just like in John tired); or else I'm tired is simply an imitation of mainstream varieties of American English. Supposedly, the is of I'm is sick demonstrates not only that the use of the copula before the adjective is an importation from English grammar but also that it is not yet integrated in $\mathrm{AAE}$ grammar, hence the confusion in the application of the rule of subject-verb concord in person and number. (However, cf. D'Eloia 1973, who claims that such constructions are also attested in British folk speech.)

Alluding to AAE relative tense system (discussed in part 3), Dillard (1972: 43) points out that the copula-deletion hypothesis becomes more untenable when the construction must be understood as having past reference, as in sentence (6). No dialect of English has a rule which can delete the copula in the past tense.

He stood there and he thinkin'.

He stood there and he [was] thinking.

As for the interpretation of been in, e.g., I been sick and he been gone as involving the deletion of the English perfective auxiliary have, it has been shown that been + verb constructions (with the verb generally in the past participle) often correspond to past tense or past perfect constructions in English (Stewart 1970, and Dillard 1972). Even though there are indeed cases where a present perfect translation is admissible, as in John been (workin') here all day today 'John has been (working) here all day today,' these are not the only acceptable interpretations. In the case of these particular examples, past tense interpretations could also be acceptable in some contexts, viz., 'I was sick' and 'John was working.' The strongest case against the havedeletion hypothesis lies in the fact that constructions such as he been gone and John been took/taken the money (see Stewart 1970: 245) could hardly be related to corresponding English sentences with the perfective have. So, been could well function here as a tense marker denoting anteriority and/or remoteness.

Contra argument $\mathrm{B}$, it has been claimed that was may well be a substitute for

10 Similar misapplications of the subject-verb concord rule have been observed about other verbs too (Wolfram 1971, Fasold and Wolfram 1975). They could be used to highlight underlying differences between AAE and WANSE, and to lend more support to the creolist position (see, e.g., Brewer's 1973 diachronic analysis, based on slave narratives, which supports the thesis of decreolization.) However, D'Eloia (1973) argues that such constructions are attested in British folk speech too. (For evidence of these in WANSE, see Feagin 1979.)

11 There is evidence of such misanalysis in child language. At age 2yrs 5 mos, my daughter was not yet able to use the copula, except in exposed positions. However, forms such as I' $m$ and tha's were common in her speech. When occasionally prompted to repeat, after me, $I$ am, she usually produced I'm am. By her third birthday, the copula was still more absent than present in the present progressive and in future constructions with gon. 
the creole bin/ben for anterior (i.e., when the time reference of the described event precedes that of another event taken as reference point in the discourse). As with the PC bin/ben or the AAE been, was can often be omitted once the context of time reference is clear (as in many narratives reported in the linguistic literature). The construction We tired could be interpreted to refer to the past or the present, depending on the reference time in relation to which it is used in the discourse.

A point has also been made in Mufwene (1983a) against Labov's particular decision to represent his statistics of the distribution of the copula as in Diagram A rather than as below in Diagram B:

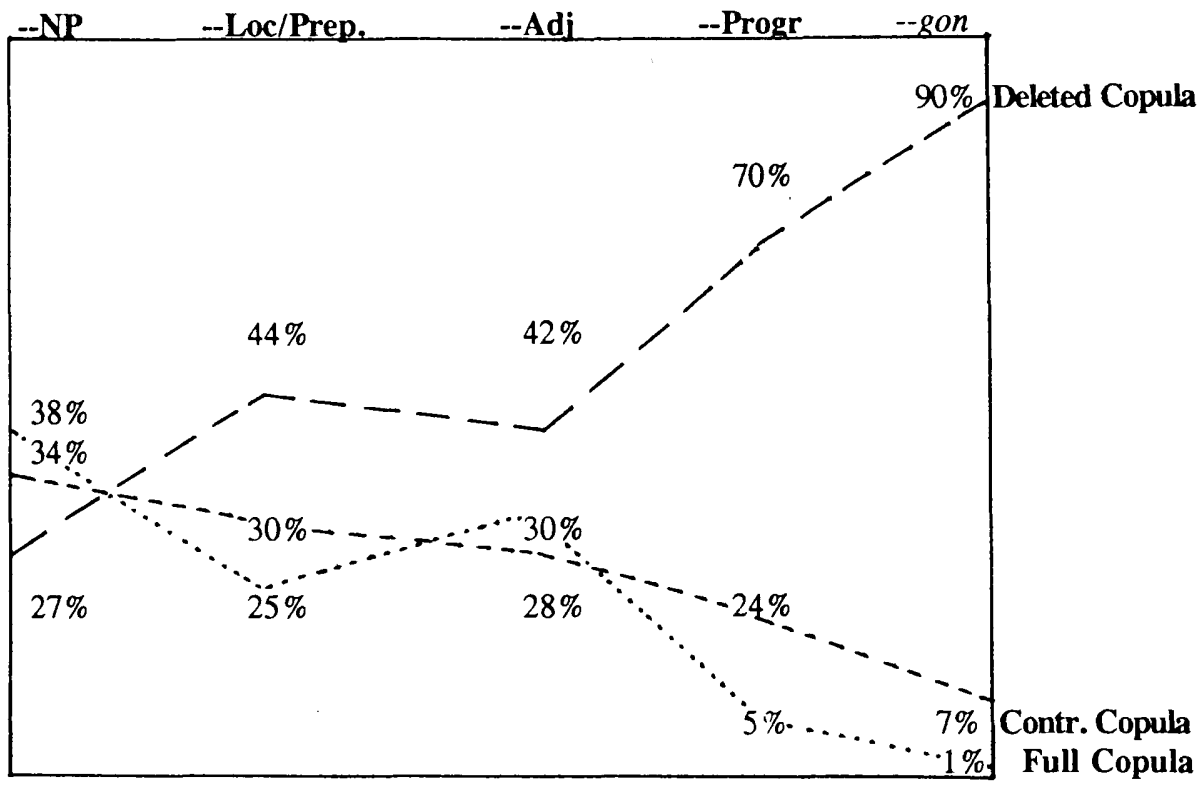

\section{Diagram B}

Even though Diagram A presents the figures in a way that highlights the complementary distribution among the occurrences of the zero, contracted, and full copulas, it also biases the facts in suggesting without independent proof that AAE is indeed one of the many dialects of English and has not by any chance come to resemble the distribution of copula in WANSE through "sprachbund" (a situation where languages which have coexisted for long periods of time have influenced one another to the point 
of having quite similar structures). ${ }^{12}$ The kind of evidence needed to help him select between Diagram A and Diagram B is simply missing in Labov's work. Based on Botkin's (1945) transcription of AAE in the 19th century, Fasold (1976) indicates that with regard to the copula the early system must have been closer to the creole system than it is today. Holm (1976, 1984), Baugh (1980) Mufwene (1983a) and Dillard (1985) all indicate that the copula is omitted the most in AAE just in those contexts where it is normally missing in the basilects of English-related Caribbean creoles, viz., in durative and future constructions, before adjectival predicates (which are assimilated to verbs), and in locative constructions. In the following examples from Jamaican Creole, the $a$ marker of the durative in (7a-c) is basically the same locative preposition in (7d), which is optionally used with the locative copula de (Mufwene 1983b): ${ }^{13}$

(7) a. Grita o sik. 'Greta is sick.'

b. Grita o a taak. 'Greta is talking.'

c. Grita o a go taak. 'Greta will talk.'

G. DURATIVE go talk (Lit., 'G. is going to talk')

d. Grita ben (de) a mi yaad. 'Greta was at my house.'

Locative constructions are built with prepositions, which, according to Mufwene (1983b), are often also assimilated to verbs in predicative functions, in which the copula is used optionally. As established by Generative Semantics studies such as Ross (1969), durative/progressive constructions are an extension of the locative construction (see also Mufwene 1984a for more cross-linguistic examples). In Guyanese Creole, as in Gullah, exactly the same locative copula [d $\epsilon$ ] and [də] respectively, is used for both locative and durative constructions (see Mufwene 1983b, 1986a). Future constructions are derived by the process of verb serialization in Jamaican and Guyanese Creoles (Mufwene 1983b) and involve no copula. Thus the high frequency of zero copula in all the above contexts in AAE (especially in those environments that are more verblike) should support the creolist hypothesis of its origin, contra the dialectologist hypothesis. (See Rickford 1977 for a slightly different interpretation of facts.)

Nonetheless, creolists do have their shortcomings too. The copula is not missing completely in creoles. Predicative noun phrases are normally linked to their subjects with what Bailey (1965) calls "equative copula," as in Tony a mi breda "Tony is my brother'. As shown in Mufwene (1983a, 1984b), this equative $a$ is not the same as the locative/durative $a$. Unlike the latter, it changes into ton 'turn' in the future (see also Winford 1990), as in im a go ton mi fren 'he will be my friend'. Thus, the fact that, according to Labov's (1969) analysis, the copula is zero $27 \%$ times before predicative noun phrases while it is normally expected in the same environment in an English

${ }^{12}$ I am now less committed than Mufwene (1983a) to the similarity-through-sprachbund thesis, having questioned the hypothesis that $\mathrm{AAE}$ is an erstwhile creole that has decreolized (Mufwene 1987).

13 See Winford (1990) for a more elaborate discussion of the syntactic and sociolectal distribution of the copula in Guyanese Creole. 
creole is a distributional generalization which calls for some explanations from creolists.

Even the fact that the statistics for zero copula are lower before adjectival predicates than in progressive/durative and future constructions calls for some explanations too. In English creoles neither context calls for a copula! The figures of Labov's analysis raise relevant questions over the creolist position.

Also, unlike adjectival predicates, locative constructions allow an optional copula as in Grita (de) a mi yaad 'Greta is at my house.' If the distribution of the copula in $\mathrm{AAE}$ (in terms of its presence and absence in a sentence) were parallel to the creole system, then the frequency of the zero copula should be higher for adjectives than for locative constructions. No explanation has been provided so far for the fact that the figures do not corroborate this hypothesis. In addition, the obligatory presence of the copula in some of Labov's "exposed position," such as before the infinitive cannot simply be ignored. Even if decreolization is invoked, the general claim is that the progressive replacement of acrolectal for basilectal forms is consistent with the distribution of forms in the basilect. In the particular case of the infinitive, the basilect has no such environment; Atlantic creoles are assumed not to have a finite/nonfinite distinction (Bickerton 1984; Mufwene and Dijkhoff 1989).

Lastly, the claim that I'm in I'm am sick is just an alternative form of the pronoun $I$ may be disputed. So far constructions such as *I'm read 'I read' have not been reported. They would have been possible if I' $m$ were just an alternative pronoun. That I'm read is even considered incorrect by AAE speakers suggests that the creolist explanation for I'm in I'm am sick may not be adequate (contrary to my previous endorsement of it in Mufwene 1983a).

The situation is thus rather inconclusive for both creolists and dialectologists. Considering all the supportive evidence adduced by both sides, there is no question that the positions were based on facts, however incomplete these are. On the other hand, the way in which counter-evidence has been disregarded suggests that neither side is willing to question the working assumptions of its own paradigm and to consider alternative hypotheses without necessarily yielding (completely) to the opponent views. Paradigmatic commitment seems to be the fundamental obstacle. More on this in part 5.

\section{Time reference}

Quite a number of things can be discussed under this heading, including negators which are overlooked here due to lack of space. Only a few aspects of this topic are discussed to further highlight the role of paradigmatic bias in sustaining some positions that have been taken in the literature. For instance, Mufwene (1983a) emphasizes the hypothesis that the basilect of AAE must have a fundamentally "relative tense" system (like Caribbean English creoles, as opposed to the English "absolute[-relative] tense" 
system involving tense re-orientation in reported speech). ${ }^{14}$ This point was suggested earlier in Stewart (1968/75: 243) and Dillard (1972: 41f), adducing sentences such as:
a. We was eatin' and we drinkin' too.
We were eating and we [were] drinking too.
b. He stood there and he thinkin'. (same as sentence (6))

Here, we drinkin' must be interpreted with reference to the past time of we was eatin'. It would have been interpreted with reference to the speech event time, i. e., in the present, if it had been used alone, related to no other clause with past time reference. The same applies, mutatis mutandis, to the interpretation of he thinkin' in sentence $(8 \mathrm{~b})$.

The thesis of "relative tense system" for AAE is of course based on partial data, and it can in fact be disputed by the following sentences (taken from Labov 1972d), which involve tense re-orientation, just like in mainstream varieties of English. Note particularly the use of wouldn't and was! Without changing the meanings, the acceptable alternates ain't go and zero copula would have been more consistent with the claim of relative tense system.

(9) a. ... three weeks ago I had a fight with this other dude outside. He got mad 'cause I wouldn't give him a cigarette.

b. I thought I was gonna drown, you know.

In the face of such counter-evidence the only way out for creolists would be to invoke decreolization. However, there is for this no historical evidence consisting of earlier native speakers' speech in which the time reference system is that of the basilect of creoles. Despite its shortcomings (see Wolfram 1990; G. Bailey to appear), Schneider (1989), the best-historically based study of AAE to date, concludes that the AAE grammar has not changed for the past one hundred years or so. ${ }^{15}$ Incidentally, the basilect of Jamaican Creole uses wuda (from English would've) for future in the past, instead of ben go (like the Guyanese Creole bin go) or simply go (which is more consistent with a relative tense system).

It has also been claimed that Jamaican Creole is more decreolized than Guyanese Creole; but it remains an open question whether from their inceptions both

\footnotetext{
14 A relative tense system is that where the reference point for a described event need not be the speech event time but may be any other event in the discourse. On the other hand, a tense system is absolute-relative when the reference time of the described events is coded not only in relation to other event in the discourse but also in relation to the speech event time. The use of would in English for future in the past is a good example of tense re-orientation in the latter tense system. In sentence (9a), for instance, wouldn't denotes future relative to the event of getting mad and also past relative to the speech event time.

${ }^{15}$ As observed in Mufwene (1991a, 1991b), decreolization would have actually been more likely during the past fifty years or so, the period during which more African Americans, relatively speaking, have had competitive education and have been able to move upward socio-economically.
} 
Jamaican Creole and AAE did not just select some forms and rules that distinguish them from other Black speech varieties in the New World (see Mufwene 1987, 1988 regarding $\mathrm{AAE}$ and Gullah). If this is the case, dialectologists may use the evidence of would and was in sentences (9) against the relative tense system hypothesis, even though the evidence of sentences (8) does also dispute the alternative hypothesis of absolute-relative tense system.

Mufwene (1983a) also disputes the legitimacy of assuming that AAE has distinctions such as "past tense," and "present" and "past perfect tenses," as described in Fasold and Wolfram (1975) [and more generally in discussions of past-tense-suffix deletion by dialectologists]. More explicitly, dialectologists have argued that in sentences such as (10) the past tense suffix -ed is deleted, in sentences such as (11) the perfective auxiliary have is deleted, and in sentences such as (12) the third person singular suffix $s$ of the present tense is deleted:

(10) a. John work here yesterday.

b. Mary play hookey last week.

c. Henry lift 200 lbs this morning.

d. The dog wag he tail when he saw Joe.

(11) a. I been home all day.

b. Henry done his assignment.

(12) a. John work with me now.

b. Mary play hookey these days.

c. Henry lift $200 \mathrm{lbs}$ every morning.

d. The dog wag he tail when he see Joe now.

Creolists have argued that the deletion hypothesis is not consistent with verbs that form their past tense by suppletion, e.g., win vs. won, or run vs. ran. Thus the deletion hypothesis could not account for a sentence such as John run roun the block yesterday 'John ran around the block yesterday,' which must be negated with ain't or didn't rather than don't (Dillard 1972). See:

(13) a. John ain' run roun the block yesterday.

b. John didn' run roun the block yesterday.

c. 'John don' run roun the block yesterday.

On the other hand, interpreting sentences such as in (11) as involving strictly the present perfect would preclude their delimitation with time adverbs such as yesterday, which are restricted to past tense in English grammar (Mufwene 1983a; see also Loflin, Sobin \& Dillard 1973 for co-occurrences of tense forms and time adverbials). Yet it is possible to say:

(14) a. I been home all day yesterday. 'I was home all day yesterday.'

b. Henry done his assignment last week. 'Henry did his assignment last week.'

Thus, it must be misguided to describe the above tense delimitations too readily with the terminology for English grammar, and creolists do have a point here. As in 
English PCs, been and done also combine with one another and with other verbs in a manner that does not support the have-deletion hypothesis (Stewart 1968; Dillard 1972). See:

(15) a. John done ate when I came. 'John had already eaten when I came.'

b. Sharon been gone when George come back. Sharon had gone (a long time ago) when George came back.

c. He done been work. '?(Until recently) he worked a long time ago.'

d. He been done work. 'He finished working quite a while ago.'

Sentences (15c-d) are from Fickett (1972:19) and involve the so-called stressed been also discussed by Stewart (1965), Loflin (1970), Dillard (1972), and more elaborately by Rickford $(1975,1977)$. The question mark before the translation of $(15 \mathrm{c})$ indicates doubts of some native speakers about the translation and the construction itself. Although the usage of this stressed been does not seem to be quite clearcut from that of the unstressed been for the PC anterior tense-a possible interpretation of sentence (15b)-it seems to denote remoteness and perhaps also completeness, particularly with non-stative verbs, such as go and work. In some contexts, however, its usage appears to be related to that of the English perfect progressive (see D'Eloia 1973; Rickford 1977; Schneider 1983), e.g., Mary been workin here for a week now. That this stressed been can apparently alternate positions with the true aspectual marker done suggests that it must have some aspectual component in its meaning, since aspectual markers are normally closer to the verbs they delimit than tense markers. Note also that the meanings of the sentences change accordingly, depending on which of the two markers comes first. On the other hand, some AAE speakers find sentence (15c) rather unnatural and not semantically different from (15d). It is possible that stressed been is essentially a tense marker, as Art Spears (personal communication) has pointed out to me. It is yet necessary to account for the its perfective-like use in Mary been workin here for a week now.

Regarding the translation of been in (15b) by the English past perfect, this does not justify treating it as past perfect marker (cf. Fasold and Wolfram 1975), since it can be translated by the present perfect, as in sentence (11a) or in I been know(in') you for a long time 'I've known you for a long time.'

Done in (15a) also plays the same perfective aspectual function as in English PCs. According to Dillard (1972), it denotes recent completion or beginning of a continuing state of affairs relative to a reference time. It is only because of the time of the event denoted by come that it must be translated as 'past perfect' in sentence (15a).

Correlated with the above discussion of time reference is the matter of subjectverb in AAE. Creolists have argued that, as in creole grammar, AAE does not have a person and number concord rule for the subject and the verb in the present tense (used actually for habits with non-stative verbs such as in (12)). Further support for this lies in the invariant use of don't and do as in: 
Jane does not tell lies like Carol does.

However, as much strength as the creolist position may derive from the above, not all facts are consistent with it. Despite the thesis of decreolization, the fact that in AAE verbs are delimited in the progressive by suffixing -in', rather than prefixing the marker $d \epsilon / d \partial a$ (as in Atlantic English PCs), relates the vernacular somehow to English too, particularly since both language varieties have similar distributions for the progressive. $\mathrm{AAE}$ also has a distributive be that combines with non-stative verbs in the progressive, and with adjectival predicates, prepositional and locative adverbial phrases (Fasold 1969) as below:
a. $\quad$ Sometimes he just be joking. (Fasold 1969)
b. $\quad$ Every time I get in a fight, they be smaller than me. (idem)
c. He be done ate [every time I visit him]. (DeBose 1984b)

Although this kind of aspectual construction does not seem to be common in many varieties of WANSE (see, e.g., Fasold \& Wolfram 1975), it is attested, according to Bailey \& Bassett (1986) and Bailey \& Maynor (1987), in white folk speech too. (Bailey \& Maynor claim, however, that AAE is developing a distribution of its own, since, according to their investigation, the younger generation is increasingly using it also with the progressive, unlike in WANSE or the older, traditional black folk speech.) Of English PCs Gullah is to my knowledge the only one which uses the distributive be. I know of no other PC basilect reported to have it. Barbadian, Guyanese and Trinidadian creoles, and even Gullah (also) use $d o z$ (Rickford 1974; pronounced [dəzz] in my Gullah field texts), and Krio uses blant (Hancock 1986). Other PCs (and sometimes even the above) use either the durative or the unmarked form of the verb for habits. As noted in Mufwene (1984b), creolists should be hard-pressed with explaining this peculiarity of, or development in, AAE in invoking decreolization.

Also, even though the role of substrate influence has not been completely ruled out, this distributive be has been traced back to Irish-Scottish English, with some reservation by Wolfram (1971), partially by Rickford $(1975,1986)$, and with more certainty by Labov (1972b), Rickford (1974), and Crozier (1984). According to D'Eloia (1973), it was common in sixteenth-century England. Its use in AAE may well be a selection (and preservation, with possible reinforcing substrate influence) of a feature which was certainly attested in some varieties of either maritime or "colonial English"16 and may be falling out use in WANSE. (Part 5 explains how this inference can make sense without necessarily espousing either the dialectologist or the creolist positions.)

In a different vein, the fact that AAE's stressed been is lacking in English PCs (Rickford 1977) just complicates the genetic scenario. As noted above, this tenseaspect marker shows partial affinity to the English progressive perfective construction

16 This term is used here to refer to several varieties that could have been in use in the New World in the seventeenth and eighteenth centuries. 
in being possibly a combination of both tense and aspect marking (unlike the PC unstressed been for anterior tense). On the other hand, it cannot be claimed that this affinity to English is due to decreolization, because its pattern of usage is not quite English either (Fasold 1969; Rickford 1977). The construction been done plus verb is not attested in English, nor is the construction been know(in'). Dillard (1972) also notes that this been is in complementary distribution with the perfective marker done in that been done denotes 'remote perfect' (applying to something that took place or started in a distant past) while done implicates 'near perfect'; no such contrast in Atlantic English PCs.

Aspectual done is no surer connection to Atlantic PCs either. Feagin (1979) includes a brief historical survey of its usage in white speech since Middle English (see also D'Eloia 1973). Consistently with part 5 and even with Dillard's (1985) hypothesis that colonial English in the USA must have been more influenced by sixteenth- and seventeenth-century maritime English than so far acknowledged, this observation suggests that both $\mathrm{AAE}$ and WANSE may have developed their usages of done parallelly without borrowing from one another but perhaps reinforcing one another. Insofar as AAE is concerned, the ultimate question remains of the conditions under which superstrate or substrate influence, or even innovations, each ruled out the others.

In yet a different vein, note the modal/aspectual constructions with come plus a non-stative verb in the present participle to denote resentment and/or indignation (Spears 1982) and with steady also plus a non-stative verb in the present participle [or, according to my informants, with some prepositional phrases] to denote persistence Baugh (1983a, 1984). These are illustrated below unfortunately without their discourse contexts, which normally highlight these meanings.

(18) a. He come walkin' in here like he owned the damn place.

b. She be steady running her mouth.

c. She steady be with that nasty boy leven though everybody told her to dump him.$^{17}$

These constructions with come and steady have counterparts in neither English nor PC grammar. Worth mentioning in connection with these markers is the imminent future construction with fixin' to (contracted to fi'na [fi?nd], with a medial glottal stop) commonly used by both African Americans and Whites in the southern USA. ${ }^{18}$ To my knowledge it is not used in Atlantic English PCs. Once more, we are deadlocked in a no-win situation; the data are not wholly consistent with either the dialectologist

${ }^{17}$ Art Spears (personal communication) argues that steady in sentences (18b-c) is just a regular time adverb and not an aspectual marker. One of his reasons is that its position can vary even in more ways than illustrated in these examples; it can apparently also occur sentence-finally without any change in the meaning of the same sentences. True aspect and tense markers tend to have fixed posi-tions relative to the verb they delimit.

18 This feature was reported earlier by DeBose (1984b) about AAE in Oakland, California. I have also heard it from an AAE speaker in Los Angeles, and it seems to be common in Georgia. 
or the creolist positions in their traditional formulations. In fact they show shortcomings that make them each an unacceptable alternative to the other. On the other hand, both positions do make some correct observations about AAE grammar, although the claimed connections of the language variety to both WANSE and PCs remain partial and, I may add, need not have been inherited (or copied) from these varieties. On an analogy with population genetics, it is possible that both similar and different features from a common parent (i.e., various nonstandard varieties of British English and seventeenth-century maritime English) have been transmitted into WANSE, AAE, and English PCs. As far as all facts of AAE grammar are concerned, it seems necessary for both to consider alternatives other than those suggested by the paradigms in which they are formulated.

To put things differently, nothing more than paradigmatic bias explains why the dialectologist and creolist positions have not been abandoned for a fresh approach. It is just as though, for dialectologists, rejecting the assumption that AAE is one of the WANSE varieties (even if it may have come from a creole) may be too high a price to pay. Likewise, creolists do not want to consider the possibility that AAE may never have been a creole but just happens to share some features with Atlantic PCs. Yet considering the fact that WANSE, AAE, and Atlantic English PCs all had varieties of English as their lexifier, it is not surprising that they also share some grammatical features with one another. But it is not at all necessary to account for these similarities by relating AAE to either WANSE or Atlantic English PCs in a daughter-to-mother kind of kinship. However, before continuing with these reflections, let us see why the substratist position is even more untenable than the above alternatives.

\section{The substratist position}

Substratists have generally tended to relate the features of AAE and PCs that are unEnglish ultimately to some aspects of the grammars of some African language(s). What has made it the least attractive of all positions is in part the fact that it does not account for variation among African languages regarding the same features under consideration. Mufwene (1986d) argues that where African influence is demonstrated, it would have to be selective, possibly regulated by some universal principles which must rank grammatical features (see also Mufwene 1991d). These universal selective principles would explain why the features of some West-African languages would have been selected over those of other languages. Thus, as discussed in Mufwene (1985a) it is misleading to speak broadly of African linguistic substratum, survivals, continuities, or retentions. One of the strongest and soundest arguments against substratism appears in Frajzyngier (1984) about the complementizer usage of say in AAE and English PCs as below:

(19) a. He tole Sharon say ain' nobody call you here. He told Sharon that nobody (had) invited her there/here. 
b. He aks me say you gone an' come back already?

He asked me if/whether I had gone and come back already.

To be sure, say is used here in an un-English way to mark the beginning of a complement sentence. Also these constructions do indeed have parallels or models in Kwa languages and are related to serialized verb constructions. But the morpheme say is English (or at least it has been selected from it), which suggests only possible African influence (even if only corroborating). But, objects Frajzyngier, if the influence is so African, why has a similar pattern not developed in French-related creoles, such as Haitian? In the latter PCs, the pattern is similar to that of French, and embedded sentences are introduced by French-derived morphemes which have nothing to do with the meaning 'say'.

The old substratist position with regard to AAE and several PCs (Mufwene 1990) has relied on some random coincidences of aspects of Atlantic PC grammars with those of some African languages, overlooking the fact that there are often important structural differences among African languages in general and even West-African languages in particular (see Mufwene 1986d) as well as the fact these similarities also obtain between these PCs and languages as unrelated as Chinese and Thai (see Mufwene 1986c). Below, my final, global comments will disregard the substratist position, which is also rejected in Mufwene (1983a), even though there is no question that there is some selective influence in some aspects of African American speech varieties in general (see Mufwene 1985a). As stated below, this does not entail victory for the dialectologist position (at least in the most extreme version of Krapp 1924 and Kurath 1928), which, in the first place, prompted both the substratist and creolist. reactions because of some obvious inadequacies.

\section{In conclusion}

Parts 2-3 show that neither the dialectologist nor the creolist position accounts adequately for all the facts of AAE. ${ }^{19}$ The traditional dialectologist claim of conservatism in $\mathrm{AAE}$ fails particularly to account for those features (especially structural) that cannot be traced to either colonial English nor any nonstandard variety of British English, e.g., the current use of stressed been or come plus a verb in the present participle to express resentment. The creolist assumption of decreolization also fails to account for these same respects in which AAE differs from both English PCs and any English varieties spoken today or earlier in the USA and the United Kingdom. Attempts to account for the facts of AAE rigidly within either framework is thus like driving on a dead-end street, staying away from the destination.

As suggested in Mufwene (1984b), the solution out of this apparent impasse in studies of AAE (and New World PCs) may lie in assuming the following. During the

${ }^{19}$ Bailey \& Maynor (1987) draw a similar conclusion, although this is based on different considerations. 
colonial settlements in the New World, new language varieties developed based in part on "colonial English," hence many a feature shared by these varieties that have caught the attention of numerous opponents of the creolist/substratist position as the exclusive account (more recently, Schneider 1982, 1983, 1989). These new language varieties need not have developed sequentially, one based on another; in fact they must have developed concomitantly, and contacts among the colonies must have provided opportunities for them to influence one another too. But just in the same way that mutual influence does not mean homogenization of all these varieties, various factors in their parallel developments ${ }^{20}$ account for differences among them. As discussed in Mufwene (1986d), the natures of the linguistic contacts in the New World or the forts of West Africa left room for various influences. As also argued in Mufwene (1986a), the very fact that the Africans aimed at speaking the colonial language (see also Dalby 1971) opened the door to many English-like features in the case of AAE, particularly regarding the selection of forms (as discussed more explicitly now in Mufwene 1991d). However, this approach does not justify the assumption that a grammar similar to that of WANSE underlies AAE, just like the (partial) typological relatedness of $\mathrm{AAE}$ to English PCs is not sufficient justification for assuming that it must have decreolized from a Gullah-like plantation creole. Mufwene (1984b) argues that the assumption of the putative process of decreolization from the reality of speech continua in the New World may have been misguided. All along, there must have been a continuum of speech forms from the least to the most English-like (see also Herskovits 1941; Alleyne 1980; Schneider 1982) ${ }^{21}$.

Based on the above assumptions, it seems that a fresh start should consist in analyzing AAE as an independent system (as though we did not know its historical connections with either English or English PCs) and undertaking comparisons with these other varieties only after we understand the structure of the system independently. As Loflin (1970: 27) phrased it, "we must have [independent] grammars before we can claim anything about the nature of differences [and similarities] between grammars," 22

20 These factors are well captured by Bickerton's (1984) notion of "pidginization index," which in the context of this paper subsumes in part the following: the proportion of the native speakers to that of the learners of the target language, the proportion of additional generations of second-language learners to that of the first generation (which must have played a central role in developing the new language variety), the kind of social contact between the native speakers and the learners, the variety or varieties most commonly heard from the native speakers, and whether or not the contact between the two groups continued after the formation of the new language variety. A necessary complement to Bickerton's approach is Mufwene's (1991d) list of factors that determine markedness in the selection of linguistic features.

${ }^{21}$ Mufwene (1991a, 1991b) now elaborates on the thesis of continuum since inception in the context of Gullah.

22 Needless to say this position is different from that in Baugh (1983a\&b), where it is claimed that the creolist and dialectologist positions are complementary. As pointed out in Mufwene (1985b) with regard to the genetic assumptions of these positions, AAE cannot be both an English dialect and 
and this is missing to date. This approach does not of course preclude noting structural similarities between AAE and English PCs, contextual similarities in the application of some rules of AAE with some other rules of WANSE, and even genetic relations between AAE and any variety of English. But it also makes us weary of some misidentifications, the kind of things that B. Bailey (1965: 175) cautions creolists against.

Another respect in which both dialectologists and creolists reflect their ideological orientations or paradigmatic biases is the assumption that the system of any particular language variety must be homogeneous, in the sense that only the same kinds of rules and exactly the same system are followed by all speakers to produce the same kinds of utterances in the same lect, or even that languages have consistent grammatical systems (in which no rules conflict with one another). The observation in part 3 about whether AAE has a relative or absolute tense system is worthwhile reexamining in light of this possibility. The complementizer usage of say to introduce embedded sentences is sometimes correlated with quotative reported speech (in which personal pronouns and tenses are not re-oriented), as in sentences (19), but sometimes it is accompanied with indirect reported speech (in which personal pronouns and tenses are re-oriented) ${ }^{23}$. Speakers may at one time follow one set of rules (say, the relative tense system) and at another time follow another (viz., the absolute tense system). A diglossic situation such as in the USA may very well favor the coexistence of such inconsistent aspects of grammars in the minds of the same speakers, and this may very well account for part of the variation that students of AAE (and of PCs for that matter) have had to deal with all the time. While the idea of optional rules within the same consistent system has its place quite established and justified in studies of AAE, that of inconsistent or hybrid grammar is worthwhile considering more seriously. Even languages such as English display similar "anomalies," so to speak, such as in the domain of number delimitation where a singular/nonsingular system coexists with a

a decreolized Atlantic PC at the same time. Assuming that decreolization is just one particular case of sprachbund, in which, due to continuous contact, a language L1 adopts so many forms and rules of another language L2 that it winds up resembling the latter, there is no reason to assume that L1 now becomes a dialect of L2 -- not any more than the Balkan languages should be assumed to be dialects of one another. On the other hand, a dialect using more frequently and extensively rules which are only optional in other, related dialects can in no way be assimilated to a decreolized creole. It is, however, conceivable that from its inception AAE may have had some rules that relate it rather closely to WANSE while in other respects it would have shown kinship to English PCs. But this does not make the creolist and dialectologist positions complementary; on the contrary it invalidates both and calls for another kind of analysis, which is the "fresh start" proposed in this essay.

23 Unfortunately, Frajzyngier (1984) fails to highlight this important aspect of the complementizer use of say. It is quite conceivable that one of the main reasons why say has developed into a complementizer is that, in nonstandard English, sequences such as he said/says, ... and he said/says, and he said/says occur commonly introducing quotations of characters in a discourse. It remains to be determined whether this practice is more common in English than in French, which may be the reason why a similar pattern has not developed in French creoles. 
individuated/nonindividuated system $^{24}$. This new approach to studies of language varieties in particular may turn out to be fruitful; and future research should tell us more.

\section{References}

Alleyne, M.C. (1980) Comparative Afro-American: An historical-comparative study of English-based AfroAmerican dialects of the New World. Ann Arbor: Karoma.

Bailey, B.L. (1965) "Toward a new perspective in Negro English dialectology". American Speech 40: 1717.

Bailey, G. (1987) Unititled contribution to Are black and white vernaculars diverging? Papers from the NWAVE XIV panel discussion, ed. by R. Butters, pp. 32-40. American Speech 62, \#1.

Bailey, G. (to appear) Review of Edgar Schneider (1989). Journal of Pidgin and Creole Languages.

Bailey, G. and M. Bassett (1986) "Invariant be in the Lower South". In Montgomery and Bailey: 158-79.

Bailey, G. and N. Maynor (1987) "Decreolization?" Language in Society 16: 449-73.

Baugh, J. (1980) "A re-examination of the Black English copula". In Locating language in time and space, ed. by W. Labov, 83-106. New York: Academic Press.

Baugh, J. (1983a) Black street speech: Its history, structure and survival. Austin: University of Texas Press.

Baugh, J. (1983b) "A survey of Afro-American English". Annual Review of Anthropology 12: 335-54.

Baugh, J. (1984) Steady: Progressive aspect in Black Vernacular English. American Speech 59: 3-12.

Bickerton, D. (1984) "The language bioprogram hypothesis". The Behavioral and Brain Sciences 7: 173221.

Botkin, B.A. (1945) Lay my burden down: A folk history of slavery. Chicago: University of Chicago Press.

Brewer, J. (1973) "Subject concord of be in Early Black English". American Speech 48: 5-21.

Burling, R. (1973) English in black and white. New York: Holt, Rinehart and Winston Inc.

Butters, R. (1989) The death of Black English: Divergence and convergence in black and white vernaculars. Frankfurt am Main: Peter Lang.

Crozier, A. (1984) "The Scottish-Irish influence on American English". American Speech 59: 310-31.

Dalby, D. (1971) "Communication in Africa and the New World". In Black-white speech relations, ed. by W. Wolfram \& N.H. Clarke: 99-138. Arlington, Va.: Center for Applied Linguistics.

${ }^{24}$ For a more elaborate discussion of non-monolithic grammar, see Mufwene (1991c). 
DeBose, Ch. (1984a) "Samana English: a dialect that time forgot". In Proceedings of the 9th Annual Meeting of the Berkeley Linguistics Society, ed. by Amy Dahlstrom et al.: 47-53. BLS.

DeBose, Ch. (1984b) "A reanalysis of the Black English verb system as decreolization". MS.

D'Eloia, S.G. (1973) "Issues in the analysis of Negro Nonstandard English: A review of J.L. Dillard's Black English: Its history and usage in the United States". Journal of English Linguistics 7: 87-106.

Dik, S.C. (1983) "Auxiliary and copula be in a functional grammar of English". In Linguistic categories: Auxiliaries and related puzzles, vol. 2, ed. by Frank Heny: 121-43. Dordrecht: D. Reibel Publishing Co.

Dillard, J.L. (1972) Black English: Its history and usage in the United States. New York: Random House.

Dillard, J.L. (1985) Toward a social history of American English. New York: Mouton.

Dunn, E.F. (1976) "The black-southern white dialect controversy: Who what to whom?" In Black English: A seminar, ed. by D.S. Harrison \& T. Trabasso: 105-22. Hillsdale, NJ: Lawrence Erlbaum Associates.

Fasold, R.W. (1969) "Tense and the form of be in Black English". Language 45: 763-76.

Fasold, R.W. (1976) "One hundred years from syntax to phonology". In Papers from the parasession on diachronic syntax, ed. by S. Steever, C. Walker, and S. Mufwene: 79-87. Chicago Linguistic Society.

Fasold, R.W. (1981) "The relationship between black and white speech in the South". American Speech 56: $163-89$.

Fasold, R.W. \& W. Wolfram (1975) "Some linguistic features of Negro dialect". In Black American English: Its background and its usage in the schools and in the literature, ed. by Paul Stoller. Delta.

Feagin, C. (1979) Variation and change in Alabama English: a sociolinguistic study of the white community. Washington, D.C.: Georgetown University Press.

Fickett, J.G. (1972) "Tense and aspect in Black English". Journal of English Linguistics 6: 17-19.

Fickett, J.G. (1975) "Ain't, not and don't in Black English". In Perspectives on Black English, ed. by J.L. Dillard: 86-90. The Hague: Mouton.

Frajzyngier, Z. (1984) "On the origin of say and se as complementizers in Black English and Englishbased creoles". American Speech 59: 207-10.

Gilman, C. (1981) "Pidgin languages: Form selection or simplification?" Paper read at 10th Annual Linguistic Symposium, Milwaukee: University of Wisconsin.

Hancock, I. (1986) "On the classification of Afro-Seminole Creole". In Language variety in the South: Perspectives in black and white, ed. by Michael Montgomery and Guy Bailey, 85-101. University: University of Alabama Press.

Hancock, I. (1987) "A preliminary classification of the Anglophone Atlantic creoles, with syntactic data from 33 representative dialects". In Pidgin and creole languages: Essays in memory of John E. Reinecke, ed. by Glenn Gilbert: 264-333. Honolulu: University of Hawaii Press. 
Herskovits, M.J. (1941) The myth of the Negro past. Boston: Bacon Press.

Holm, J. (1976) "Variability of the copula in Black English and its creole kin". Paper presented at First Biennial Conference of the Society for Caribbean Linguistics, Georgetown, Guyana.

Holm, J. (1984) "Variability of the copula in Black English and its creole kin". (updated and expanded version) American Speech 59: 291-309.

Holm, J. (1988) Pidgins and creoles. Vol. 1: Theory and structure. Cambridge: Cambridge University Press.

Krapp, G.P. (1924) "The English of the Negro". The American Mercury 2: 190-5.

Kurath, Hans (1928). The origin of dialectal differences in spoken American English. Modern Philology. 25.385-95.

Labov, W. (1969) "Contraction, deletion, and inherent variability of the English copula". Language 45: 714-62. (Also in Labov 1972a: 65-129).

Labov, W. (1972a) Language in the inner city: Studies in the Black English Vernacular. Philadelphia: U. of Philadelphia Press.

Labov, W. (1972b) "Is the Black English Vernacular a separate system?" In Labov 1972a: 36-64.

Labov, W. (1972c) "Negative attraction and negative concord". In Labov 1972a: 130-96.

Labov, W. (1972d) "The logic of nonstandard English". In Labov 1972a: 201-40.

Labov, W. (1982) "Objectivity and commitment in linguistic science: The case of the Black English trial in Ann Arbor". Language in Society 11. 165-201.

Loflin, M.D. (1970). "On the structure of the verb in a dialect of American Negro English". Linguistics 59: 14-28.

Loflin, M.D., N.J. Sobin, and J.L. Dillard (1973) "Auxiliary structures and time adverbs in Black American English". American Speech 48: 22-8.

McDavid, R., Jr. (1950) "Review of Turner (1949)". Language 26: 323-33.

McDavid, R., Jr. and V. McDavid (1951) "The relationship of the speech of American Negroes to the speech of Whites". American Speech 26: 3-17.

Montgomery, M. (1983) "The study of the language of Blacks and Whites in the American South". Tennessee Linguistics 2: 36-46.

Montgomery, M. and G. Bailey (1986) "Introduction". In Montgomery and Bailey: 1-29.

Montgomery, M. and G. Bailey (eds.) (1986) Language variety in the South: Perspectives in black and white. University: University of Alabama Press.

Mufwene, S.S. (1983a) Some observations on the verb in Black English Vernacular. African and AfroAmerican Studies and Research Center, Papers series 2, University of Texas at Austin. 
Mufwene, S.S. (1983b) "Observations on time reference in Jamaican and Guyanese creoles". English World-Wide 4:199-229.

Mufwene, S.S. (1984a) Stativity and the progressive. Indiana University Linguisitc Club.

Mufwene, S.S. (1984b) "Gullah and Jamaican creole: an issue on decreolization". Paper presented at Fifth Biennial Conference of the Society for Caribbean Linguistics, University of the West Indies, Kingston, Jamaica.

Mufwene, S.S. (1985a) "Misinterpreting 'linguistic continuity' charitably". Paper presented at 9th Annual Language and Culture in South Carolina Symposium, University of South Carolina, Columbia.

Mufwene, S.S. (1985b) "Review of Baugh (1983a)". American Speech 60: 161-6.

Mufwene, S.S. (1986a) "Notes on durative constructions in Jamaican and Guyanese creoles". In Varieties of English Around the World: Focus on the Caribbean, ed. by Manfred Görlach and J. Holm: 167-82. Amsterdam: John Benjamins.

Mufwene, S.S. (1986b) "Number delimitation in Gullah". American Speech 61: 33-60.

Mufwene, S.S. (1986c) "Les langues créoles peuvent-elles être définies sans allusion à leur histoire?" Etudes Créoles 9: 135-50.

Mufwene, S.S. (1986d) "The universalist and substrate hypotheses complement one another". In Substrata versus universals in creole genesis, ed. by Pieter Muysken and

Norval Smith, 129-62. Amsterdam: John Benjamins.

Mufwene, S.S. (1987) "Review article on of Montgomery and Bailey (1986)". Journal of Pidgin and Creole Languages 2: 93-110.

Mufwene, S.S. (1988) "Starting on the wrong foot". Column. Journal of Pidgin and Creole Languages 3: 109-17.

Mufwene, S.S. (1989) "How many be's are there in English?" Paper presented at 40th SECOL Meeting, Norfolk, VA.

Mufwene, S.S. (1990) "Transfer and the substrate hypothesis in creolistics". Studies in Second Language Acquisition 12.1-23.

Mufwene, S.S. (1991a) "Is Gullah decreolizing? A comparison of a speech sample of the 1930's with a speech sample of the 1980's". In The emergence of Black English: Texts and commentary, ed. by Guy Bailey, Nathalie Maynor, and Patricia Cukor-Avila, 213-30. Amsterdam: John Benjamins.

Mufwene, S.S. (1991b) "Some reasons why Gullah is not dying yet". English World-Wide 12.

Mufwene, S.S. (1991c) "Why grammars are monolithic". In The joy of grammar: A festschrift for James D. McCawley, ed. by Gary Larson, Diane Brentari, and Lynn MacLeod. Amsterdam: John Benjamins.

Mufwene, S.S. (1991d) "Pidgins, creoles, typology, and markedness". In Development and structures of creole languages: Essays in honor of Derek Bickerton, ed. by Francis Byrne \& Thom Huebner: 123-43. 
Amsterdam: John Benjamins.

Mufwene, S.S. and M.B. Dijkhoff (1989) "On the so-called "infinitive" in Atlantic creoles". Lingua 77.31952.

Rickford, J.R. (1974) "Insights of the mesolect". In Pidgins and creoles: Current trends and prospects, ed. by D. DeCamp \& Ian Hancock: 92-117. Washington, D.C.: Georgetown University Press.

Rickford, J.R. (1975) "Carrying the new wave into syntax: The case of Black English bin". In Analyzing variation in language, ed. by R.W. Fasold \& R.W. Shuy: 162-83. Washington, D.C.: Georgetown University Press.

Rickford, J.R. (1977) "The question of prior creolization of Black English". In Pidgin and creole linguistics, ed. by Albert Valdman: 190-221. Bloomington: Indiana University Press.

Rickford, J.R. (1986) "Social contact and linguistic diffusion". Language 62.245-90.

Rosenbaum, Peter (1968). Grammar II. Yorktown Heights, N.Y.: IBM.

Ross, J.R. (1969) "Auxiliaries as main verbs". In Studies in Philosophical Linguistics, ed. by W. Todd, 92117. Evanston, IL: Great Expectations.

Schneider, E.W. (1982) "On the history of Black English in the USA: Aome new evidence". English World-Wide 3: 18-46.

Schneider, E.W. (1983) "The diachronic development of the Black English perfective auxiliary phrase". Journal of English Linguistics 16: 55-64.

Schneider, E.W. (1989) American earlier Black English. University, AL: University of Alabama Press.

Schneider, E.W. (1990) "The cline of creoleness in English-oriented creoles and semi-creoles of the Caribbean". English World-Wide 11: 79- 113.

Schneider, E.W. (1992) "Africanisms in the grammar of Afro-American English: The significance of African substratum". In Africanisms in Afro-American language varieties, ed. by Salikoko S. Mufwene. Athens, GA: University of Georgia Press.

Spears, A.K. (1982) "The Black English semi-auxiliary come". Language 58: 850-72.

Spears, A.K. (1987) Unititled contribution to Are black and white vernaculars diverging? Papers from the NWAVE XIV panel discussion, ed. by Ronald Butters, pp. 48-55. American Speech 62, \#1.

Spears, A.K. (ed.) (in press). Language, symbolism, and ideology. Wayne State University Press.

Stewart, W.A. (1965) "Urban Negro speech: sociolinguistic factors affecting English teaching". In Social dialects and language learning, ed. by Roger Shuy: 10-18. Champaign, Illinois: The National Council of Teachers of English.

Stewart, W.A. (1967) "Sociolinguistic factors in the history of American Negro dialects". The Florida FL Reporter 5. (Also in Perspectives on Black English, ed. by J.L. Dillard: 222-32. The Hague: Mouton, 1975) 